\title{
The Modern Problems and Prospects of Music Formation and Art Education Development During COVID-19
}

\author{
CrossMark \\ Liubomyr Martyniv a, Alla Sokolova ${ }^{\text {b }}$, Svitlana Kurinna c, Oleh Kopeliuk ${ }^{\mathrm{d}}$, Ihor Sediuk e, \\ Olena Khomova ${ }^{f}$
}

Manuscript submitted: 30 August 2021, Manuscript revised: 18 October 2021, Accepted for publication: 29 November 2021

Corresponding Author ${ }^{\text {a }}$

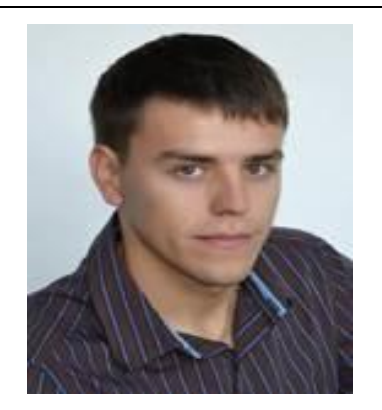

Keywords

art education;

COVID-19;

education policy;

educational environment;

educational leader;

educational process;

music education;

\section{Abstract}

This article aims to assess the problems and prospects of the development and formation of music and art education given the impact of the pandemic COVID19. Methodology. The research formed a model for the creative development of pupils and students of music and art education based on the Organization for Economic Co-operation and Development Skills for Jobs database. Results. Creativity is shaped by the hands-on activities of students, their music, and art education. Basic creativity skills are best formed through interdisciplinary collaboration toward STEM-education. Research shows that math skills, science, and engineering have a positive effect on students' creativity in handson product creation during art courses. Technical skills are important, but they stimulate creativity when students independently decide to use them in a specific, student-defined task. The novelty effect of technology is temporary in creativity stimulation, whereas the student's independent decision to use specific technical skills accordingly to a self-defined problem and task stimulates creativity in the long run. COVID-19 pandemic has exacerbated longstanding challenges and barriers for arts and music education as well as ways to solve those challenges.

a Ivan Franko Drohobych State Pedagogical University, Kyiv, Ukraine

b Odessa National A. V. Nezhdanova Academy of Music, Odessa, Ukraine

c Donbass State Pedagogical University, Sloviansk, Ukraine

d Kharkiv National University of Arts named after I.P. Kotlyarevsky, Kharkiv, Ukraine

e Kharkiv National University of Arts named after I.P. Kotlyarevsky, Kharkiv, Ukraine

f Bogomolets National Medical University, Kyiv, Ukraine 


\begin{tabular}{|c|c|c|}
\hline \multicolumn{3}{|c|}{ Contents } \\
\hline \multicolumn{3}{|c|}{ Abstract.... } \\
\hline 1 & Introduction.... & 671 \\
\hline 2 & Materials and Methods ..................................................... & 673 \\
\hline 3 & 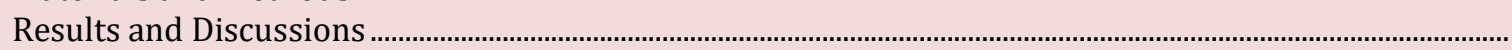 & 674 \\
\hline & 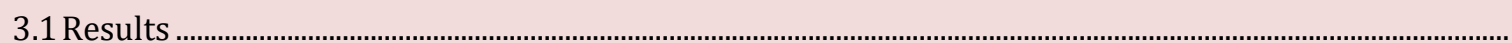 & 674 \\
\hline & 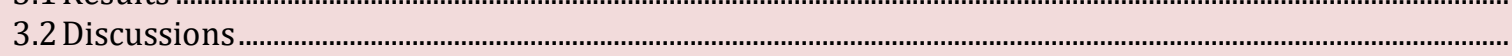 & 675 \\
\hline 4 & 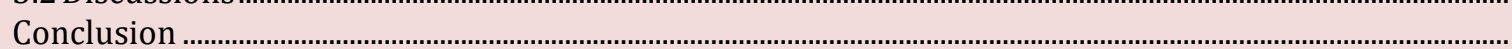 & 676 \\
\hline & Acknowledgments. & 677 \\
\hline & 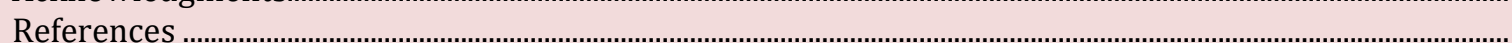 & 678 \\
\hline & Biography of Authors & 680 \\
\hline
\end{tabular}

\section{Introduction}

The development and formation of music and art education occur against the background of common problems for different countries: the integration of technology in the processes of learning, teaching, inclusive education, cooperation, the need to develop digital, cognitive, creative skills of students (Stes et al., 2010). These problems provide an opportunity to consider the prospects of development. For example, STEAMeducation, which assumes the formation of theory and knowledge in the process of practical activity of teachers, pupils, and students as equal participants of education based on joint work, becomes more and more popular. Separate problematic discussion about the development of the creative skills, in particular, in the process of using technology in music and art education as a tool to display the ideas of participants in the educational process ((Topoğlu, 2014; Corakli \& Batibay, 2012). In the time of gaining popularity of problemoriented approach and the need for cognitive skills (critical thinking, ability to solve problems and tasks, purposefulness, social skills), creativity is especially relevant as a personal ability (Rothenberg, 1990). It is the characteristic of sustainability that is peculiar to the creative personality. This article aims to assess the problems and perspectives of the development and formation of music and art education (Betts, 2006).

\section{Literature review}

Creativity in arts education has been the most frequently examined in research (Heise, 2014; Black \& Browning, 2011; Guyotte, 2015; Zimmerman, 2010; Kirsten, 2021; Vuk \& Bosnar, 2021). Creativity is viewed as a quality of personality (Dissanayake, 1995). Flach (1988), prove the next: creative individuals have problem-solving skills, but at the same time such person open to new tasks and experience. "One of the most important elements of creativity goes beyond exploring novel ways of problem-solving by considering innovative thinking on problem finding within a particular cultural context" (Han, 2019). Henderson et al. (2007), argued that creativity is characterized by an individual's problem-solving ability, autonomy, purposefulness, and social competence. These skills provide individual resilience. Wolin \& Wolin (2010), noted that creativity is the one of human resilience quality.

In an era of active development and integration of ICT into the arts, creativity is often seen in the context of using digital technology as a tool to create a product (Silvia, 2008). Creativity includes discovery, curiosity, invention, imagination, exploration and experimentation. The transformation process happens during creative digital activity that mean person start to understand something new (Black \& Browning, 2011). The term "digital art" has been formed in the literature to include more than the usual use of software in artistic practice. A crucial aspect of such process is to understand how students express their ideas and personality, and what happens during digital creation (Kusumajaya, 2021). Like in traditional art, digital one is require from person to be able to hypothesize, imagine and appreciate the transformational activity significance (Black \& Browning, 2011). In the context of digital art, it is important to take a hands-on approach to teach it and recognize that students do not need to possess large amounts of knowledge, software information. Students and learners can master the software and develop digital skills by creating a musical, artistic product

Martyniv, L., Sokolova, A., Kurinna, S., Kopeliuk, O., Sediuk, I., \& Khomova, O. (2021). The modern problems and prospects of music formation and art education development during COVID-19. International Journal of Health Sciences, 5(3). https://doi.org/10.53730/ijhs.v5n3.2936 
(Sala \& Gobet, 2017; Widana et al., 2021). The most essential component are student's ideas and art processes and technology is a tool to express ideas.

Gregory (2009), who research technology in art education, argues for a decline in the use of technology in the arts over the past decade as educators have struggled with the restrictive art education policies begun from the "No Child Left Behind" Act. Sabol (2010), criticizes the impact of this act on arts education. He presented findings of a $21 \%$ reduction in funding and a $19 \%$ reduction in instructional time in arts education, which supports Gregory's (2009) study. Additional important factors that contribute to music and art educators' unwillingness to use technology in teaching include different difficulties with the software, increased stress, higher levels of teaching load, time, lack of equipment, and teacher support and training lack (Delacruz, 2009a, 2009b; Gregory, 2009). Educational leaders and policymakers can address these challenges by implementing policies to support arts education by providing better training and support for educators, reducing stress, providing more time to learn how to use technology, reducing the burden on educators, and providing resources to purchase hardware and software. However, in the wake of the 2008-2099 recession, these challenges remain pressing. Educators have a responsibility to address these issues to effectively integrate technology into music and art education (Silakarma, 2021). In particular, mentorship and finding mentors in developing educators' digital skills, creating creative, student-centered, student-centered learning plans where collaboration between educators and pupils/students on an ongoing basis, is the way to address them (Black, 2009; Gregory, 2009). As a consequence of such practices, a new trend is forming and developing in music and art education - STEAM-education. To integrate technology, art educators are planning, developing instructional strategies, and exploring ways to use technology, resulting in new pedagogical methods of instruction (Gregory, 2009; Kistan et al., 2020).

In the context of developing creativity and unlocking the creative potential of the individual in music and art, new pedagogical activities are applied, particularly in the direction of STEAM-education (Glăveanu, 2018). This direction stimulates the formation of technological knowledge and skills from practice to theory to translate ideas into reality through the latest technologies (Guyotte, 2014). STEAM-education curricula integrate science, technology, engineering, mathematics, and art through interdisciplinary collaboration and inquiry to stimulate creativity, integrate conceptual knowledge into practice, develop teamwork skills, and problem-oriented thinking. As a consequence, students develop cognitive, creative skills. Among the cognitive (informative) skills, critical thinking, in particular, problem and problem solving, analysis and evaluation, understanding, and decision making, are given the most importance in the literature. Among the creative skills, the most importance is given to the ability to develop innovative products, visualization, and the potential of the student's imagination. Consequently, Liu \& Chen (2018), found that the integration of knowledge in art practice negatively affects students' problem-solving ability, but environmental education significantly positively affects such ability of art university students (Liu \& Chen, 2018). Liu \& Chen (2018), also argue for the need for an interdisciplinary approach to creative thinking and collaboration, which is consistent with visual art practices that seek to move beyond the embrace individual dialogue, collaboration, and interdisciplinary as key creative process components (Unrath \& Mudd, 2011).

The problem of collaboration has been addressed in music and art education for some twenty years, particularly in the context of collaboration activities between teachers and students. Collaboration is defined as "collegial pedagogy" which is the foundation of a critical pedagogy that provides the potential for all participants to participate as agents rather than their practice subjects. Through collaboration, consciousness, critical thinking, and awareness of pupils and students are developed. The collaboration also involves curriculum planning not according to a template script, a universal step-by-step curriculum, but the development of artistic practice according to the characteristics of the group of pupils and students (Dewhurst, 2010; Widjaja, 2021).

The problem of cooperation in music and art education is also considered in the context of inclusion. Art education should fulfill the following tasks: engage learners and students with special educational needs for their self-expression; raise the consciousness of all art participants; ensure equal opportunities for all participants through interdisciplinary collaboration (Derby, 2011).

Thus, the scientific literature explores the problems of creativity as an ability to: visualization and integrated problem solving, the importance of STEAM-education; interdisciplinary cooperation to stimulate creativity; integration of conceptual knowledge into practice; development of teamwork skills and problem- 
oriented thinking; promoting the use of digital, technological skills in creativity (Jokela \& Huhmarniemi, 2018).

COVID-19 has upended the world and completely revamped education. In arts education, schools of all levels were closed and all face-to-face classes were canceled (Leal-Neto et al., 2020; Chauhan \& Singh, 2020). This is unprecedented as practitioners in performing arts are among the least likely educators to embrace technology. A team of researchers conducted a study examining the impacts of teaching and learning in arts due to the COVID-19 pandemic (Li \& Wong, 2021). The study revealed that the online model can work and provide the necessary rigor in teaching and learning. The impact of the COVID-19 pandemic on distance learning and how the implemented quarantine policy has affected the work of music educators has been studied by Shaw \& Mayo (2021). The results of the research showed that there are native approaches to learning modality, learning frequency and contact between teacher and student, but most teachers were more disappointed with distance learning.

\section{Materials and Methods}

The analysis of the literature allows us to form a model of creativity development in students of music and art education (see Fig. 1). The developed model was empirically tested based on the OECD Skills for Jobs database, which contains an assessment of various skill groups of students in the fields of Arts, Entertainment, and Recreation in 33 EU and OECD countries, including Argentina, Bulgaria, Cyprus, Peru, Romania, South Africa. The skill groups included: 1) basic skills (content); 2) basic skills (process); 3) social skills; 4) complex problem solving skills; 5) technical skills; 6) systems skills; 7) resource management skills.

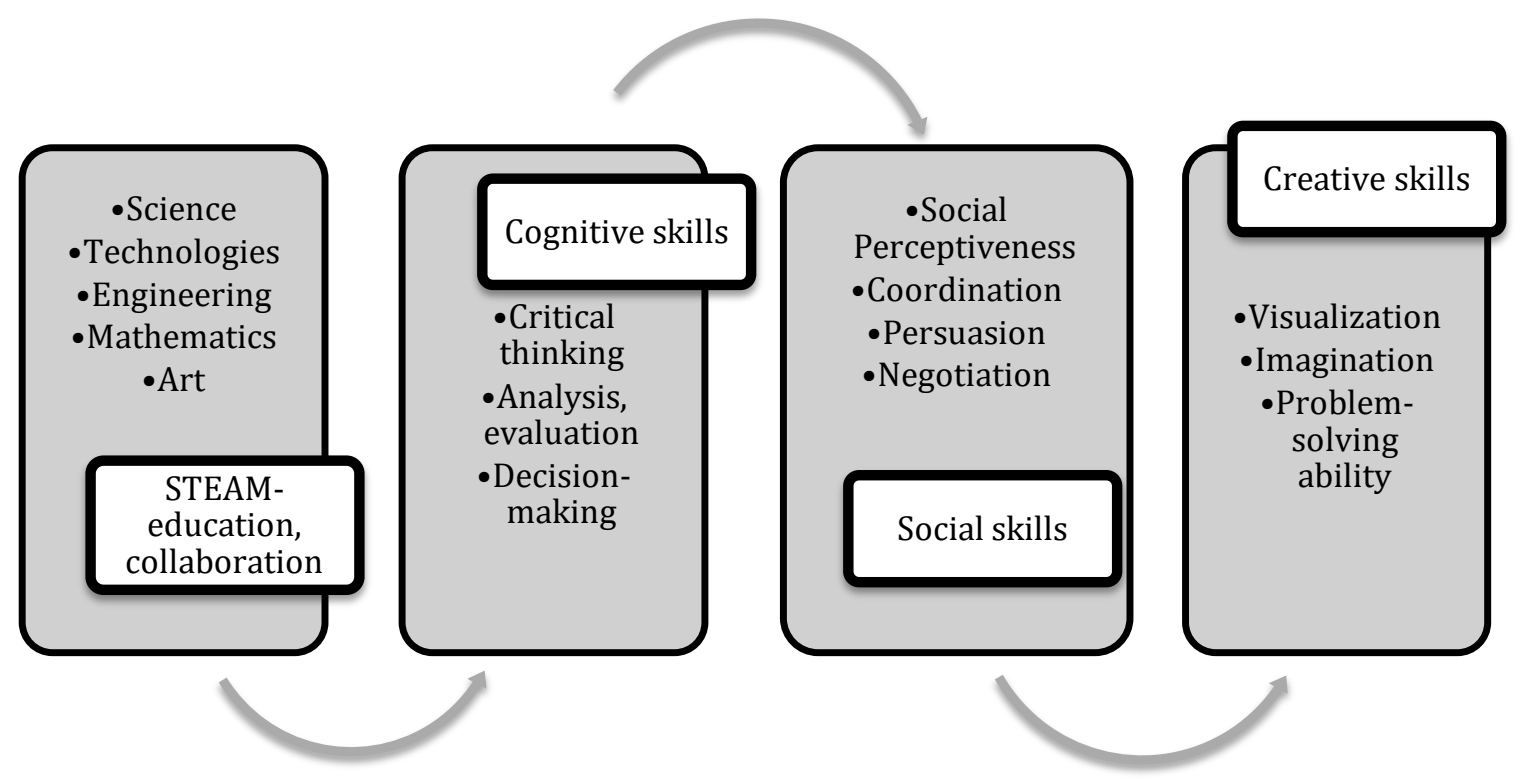

Figure 1. The model of creativity development of pupils and students of music and art education

To test the developed model of creativity formation, the following analyses of skills assessment within the groups of skills assessed in different OECD countries were used: 1) basic skills (content): mathematics skills, science; 2) basic skills (process): critical thinking; 3) social skills: general score; 4) complex problem solving skills: general score; 5) technical Skills: general score and score of technology design. To test the model, a correlation analysis of all scores was conducted, and the comprehensive problem-solving score was selected as the key variable (depending on the others) that assesses the level of creativity. The scores of the corresponding skill group characterize an excess (from -1 to 0 ) or deficit (from 0 to +1 ).

Martyniv, L., Sokolova, A., Kurinna, S., Kopeliuk, O., Sediuk, I., \& Khomova, O. (2021). The modern problems and prospects of music formation and art education development during COVID-19. International Journal of Health Sciences, 5(3). https://doi.org/10.53730/ijhs.v5n3.2936 


\section{Results and Discussions}

\subsection{Results}

For the correlation analysis the mean values, deviations from the mean value, minimum and maximum assessments of surplus/deficit of students' skills for 33 EU and OECD countries were calculated (Table 1). In general, a high level of student creativity can be noted, manifested by a low deficit (mean of 0.056) and a deviation within countries of 0.078 . The minimum value of the creativity score is -0.092 (excess), the maximum is 0.232 (deficit). Similar values of scores are also characteristic of other skills that influence creativity: mathematical (0.029), scientific (0.017), technical (0.006), technological design (0.007), critical thinking (0.070), social skills (0.05). There are also minimal differences in these skills within countries. That said, there are countries with deficits in integrated problem-solving skills, math skills, critical thinking skills, and social skills, where the maximum values in the sample reach scores of $0.232,0.121,0.289$, and 0246 , respectively. These countries include:

1) For math skills deficit: Norway 0.08, Netherlands 0.083, South Africa 0.09, Estonia 0.121;

2) For complex problem-solving skills deficit: Lithuania, Hungary, Bulgaria, Ireland, South Africa, Germany, Norway, Netherlands, Peru, Estonia with an average deficit score of 0.155 ;

3) For critical thinking skills deficit: Luxembourg, Greece, Lithuania, Hungary, Ireland, Bulgaria, South Africa, Germany, Norway, Netherlands, Peru, Estonia, in which the deficit score averages 0.180;

4) For social skills deficit: Lithuania, Bulgaria, Ireland, Hungary, South Africa, Germany, Norway, Netherlands, Estonia, Peru, in which the deficit score averages 0.1514.

Thus, countries with deficits in math skills, critical thinking skills, and social skills also show deficits in creativity (integrated problem solving) skills.

Table 1

A descriptive statistic of the different students' skills in the EU and OECD countries

\begin{tabular}{lccccccc}
\hline & $\begin{array}{c}\text { Complex } \\
\text { Problem } \\
\text { Solving } \\
\text { Skills }\end{array}$ & $\begin{array}{c}\text { Mathematics } \\
\text { Skills }\end{array}$ & Science & $\begin{array}{c}\text { Technical } \\
\text { Skills }\end{array}$ & $\begin{array}{c}\text { Technology } \\
\text { Design }\end{array}$ & $\begin{array}{c}\text { Critical } \\
\text { Thinking }\end{array}$ & $\begin{array}{c}\text { Social } \\
\text { Skills }\end{array}$ \\
\hline Average meaning & 0,056 & 0,029 & 0,017 & 0,006 & 0,007 & 0,070 & 0,050 \\
Deviation & 0,078 & 0,039 & 0,019 & 0,015 & 0,010 & 0,098 & 0,080 \\
Minimum & $-0,092$ & $-0,057$ & $-0,026$ & $-0,017$ & $-0,013$ & $-0,108$ & $-0,092$ \\
Maximum & 0,232 & 0,121 & 0,063 & 0,048 & 0,031 & 0,289 & 0,246 \\
\hline
\end{tabular}

Source: author's elaboration

Correlation analysis indicates a significant strong forward direction of the relationship between skills surplus/deficit scores: students' creativity is directly influenced by math skills, science knowledge, technical skills, particularly technological design skills, critical thinking, and social skills.

Table 2

The correlation analysis of the links: creativity and influence factors

\begin{tabular}{|c|c|c|c|c|c|c|c|}
\hline & $\begin{array}{l}\text { Complex } \\
\text { Problem } \\
\text { Solving } \\
\text { Skills } \\
\end{array}$ & $\begin{array}{c}\text { Mathematics } \\
\text { Skills }\end{array}$ & Science & $\begin{array}{l}\text { Technical } \\
\text { Skills }\end{array}$ & $\begin{array}{l}\text { Technology } \\
\text { Design }\end{array}$ & $\begin{array}{l}\text { Critical } \\
\text { Thinking }\end{array}$ & $\begin{array}{l}\text { Social } \\
\text { Skills }\end{array}$ \\
\hline Complex Problem Solving Skills & 1,000 & & & & & & \\
\hline Mathematics Skills & 0,928 & 1,000 & & & & & \\
\hline Science & 0,811 & 0,769 & 1,000 & & & & \\
\hline Technical Skills & 0,877 & 0,818 & 0,559 & 1,000 & & & \\
\hline
\end{tabular}




\begin{tabular}{llllllll}
\hline Technology Design & 0,957 & 0,938 & 0,776 & 0,858 & 1,000 & & \\
Critical Thinking & 0,998 & 0,914 & 0,789 & 0,880 & 0,947 & 1,000 \\
Social Skills & 0,984 & 0,888 & 0,728 & 0,895 & 0,940 & 0,992 & 1,000 \\
\hline
\end{tabular}

Source: author's elaboration

At the same time, all skill assessments are interrelated and directly reflected on other skills, which means that the development of creative thinking is impossible without basic, technical and social skills.

The constructed correlation matrix allows constructing a cognitive map of the model of creativity development of pupils and students of music and art education (Figure 2).

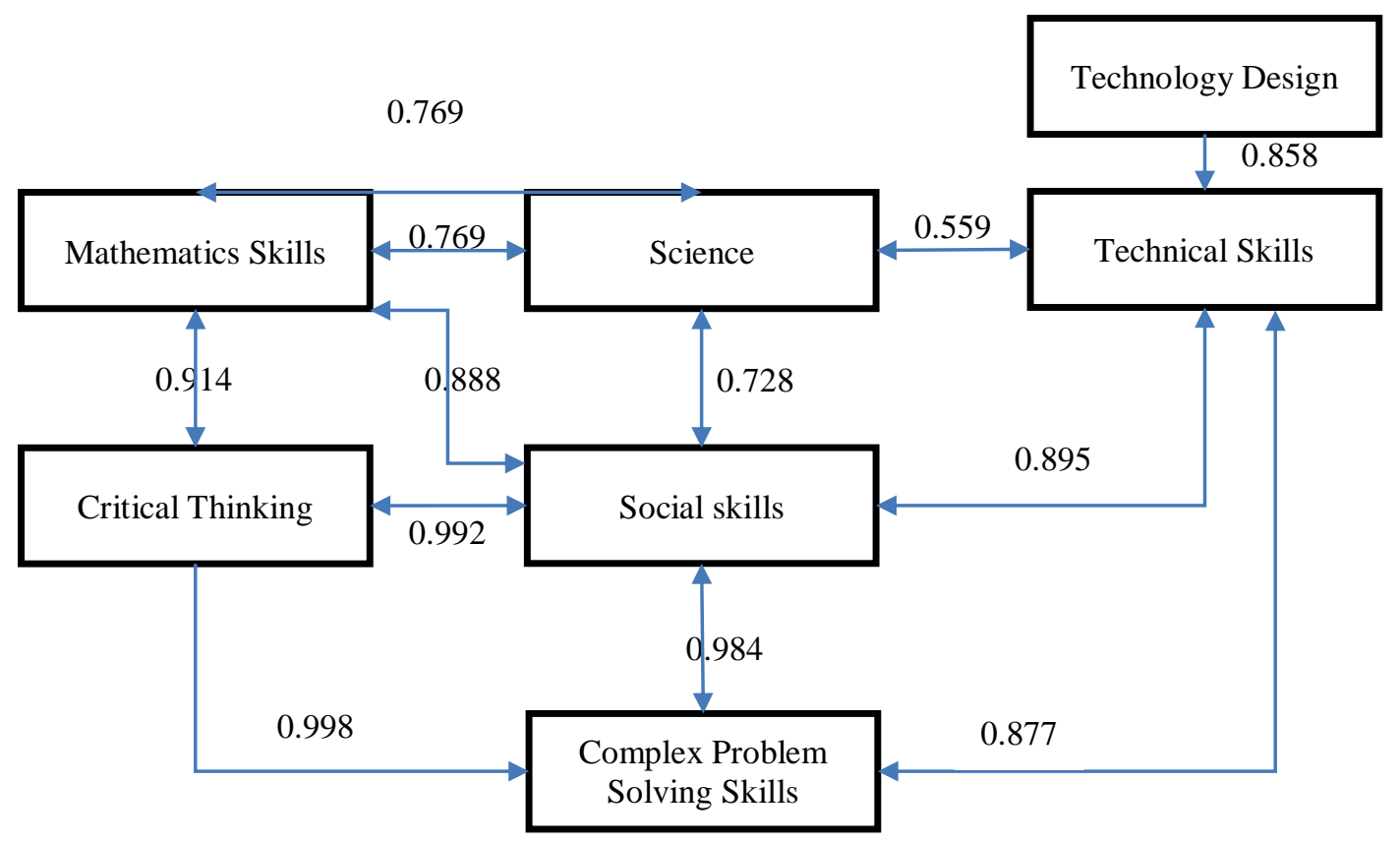

Figure 2. The cognitive map of the creativity development model of pupils and students of music and art education

Source: author's elaboration

The proposed empirical model for the development of creativity for pupils and students of music and art education is based on the assessment of their skills reflects the complex relationships between the variables of creative thinking.

\subsection{Discussions}

Han's (2019), study on stimulating creativity through the process of creating a virtual environment, pedagogical ways to stimulate student creativity identified and validated theoretical assumptions regarding the processes of developing student creativity: creativity development using technology; self-expression in creative way, individual responsibility; impact on the world art, search and problem-solving; learning as a result of group cooperation; intrinsic motivation; creativity in an educational environment.

In the use of technology, the authors also found that the student while using technology form answers to theoretical questions. The ease of finding simple answers using technology may reflect students' desire to think creatively. Han (2019), offered students tutorials, video tutorials when creating a project using software, but students preferred independent problem solving and problem-solving, which promoted creative problemsolving in art education. Students also started with simple object creation and moved on to collaborative work process, resulting in new ways of working in the software. The student's interest in the project led to them

Martyniv, L., Sokolova, A., Kurinna, S., Kopeliuk, O., Sediuk, I., \& Khomova, O. (2021). The modern problems and prospects of music formation and art education development during COVID-19. International Journal of Health Sciences, 5(3). https://doi.org/10.53730/ijhs.v5n3.2936 
solving problems that were not set by the teacher before they began. This indicated the development of knowledge, experimentation, focus on problem situations, development of new solutions to solve problems. One important finding was that collaboration can increase students' creativity; however, it can also decrease concentration. The main processes were experimenting, creating, and finding collaborative solutions.

Cotantino (2010), investigated undergraduate creativity development processes in an art education course combined with a course of engineering using visual art practice, strategies of creative problem-solving. Noting that such strategies and types of thinking theorized by art, such as "resistance to closure, tolerance of ambiguity, visualization and use of metaphor," the interdisciplinary collaboration of art and engineering provides effectiveness, particularly in the context of student creativity development.

During pandemic art education is more critical than ever when many young people feel uncertain about the future trends and disconnected from classmates. In this case, art education provides an outlet to reflect, express themselves and share their ideas, also such kinds of activities give a chance to collaborate with peers and build new connections. These advantages are supported by scientific research (Xu, 2021; Li \& Wong, 2021). Research shows that students who meet art gain more confidence, improve communication, and improve cognition and critical thinking. A review of more than 3,000 studies by the World Health Organization in 2019 also revealed the importance of art for health (World Health Organization, 2019). The results of Li \& Wong (2021), proved that device accessibility and network stability during pandemic distance learning made some problems for students and teachers, also the online environments restricted teaching and learning. Nevertheless, students counter argued that the online model provided greater flexibility and personal development. In other words, the digital era learners were more accepting of the online model than their teachers. The main barriers to art education are problems with funding and resources, a focus on correction that distracts students from art lessons, and persistent unequal access to art education for poor and colored students. At the same time pandemic has exacerbated some long-standing challenges and ways to solve those challenges (Dik et al., 2021).

Bryant (2010), defines an extremely important combination of creativity and technical skills. Creativity is defined by Bryant (2010), as an individual's use of knowledge, imagination, and judgment within the constraints of the environment and its resources to solve a problem in an innovative, quality, and appropriate way. Technology and technique share the same root techne, which means art, craft, craftsmanship (Bryant, 2010). The computer is the latest addition to the artist's toolkit for demonstrating technical skills. In today's strongest art programs, the priority is to teach content and process, to allow pupils and students to use content to express themselves artistically. However, quite often the balance of technique and creative expression found in many art classes is lost in the computer lab. Often educators assume that working with computer technology motivates students to learn technique through its novelty. However, this is often a temporary effect. Subsequently, the novelty factor diminishes, and if substantial knowledge or intrinsic motivation is lacking, artistic creative work can be suspended, and in some cases, it stops altogether.

\section{Conclusion}

Creativity is formed in the process of practical activity of pupils and students of music and art education. Basic creativity skills are best formed in the process of interdisciplinary cooperation in the direction of STEMeducation. As this research shows, math skills, science, and engineering have a positive effect on students' creativity in hands-on product creation during art courses. Technical skills are important, but they stimulate creativity when students independently decide to use them in a specific, student-defined task. The novelty effect of technology is temporary in stimulating creativity, whereas the student's independent decision to use specific technical skills accordingly to a self-defined problem and task stimulates creativity in the long run. In most cases, collaborative practical cooperation and interdisciplinary approach solve the problem of stimulating the students' creativity, their involvement in the learning process. The developed and empirically proved model of creative development of pupils and students of music and art education, due to the system of skills, proves the complex connection of different groups of knowledge, skills, and competence of students and the influence on stimulation of creativity.

COVID-19 has upended the world and completely revamped education. Arts and music studies have also experienced considerable changes, with university closures and a fluctuating return to normal and more 
limited operations. The pandemic has exacerbated long-standing problems and barriers to art and music education, as well as ways to address them, and this should be a prospect for further in-depth research.

Acknowledgments

We are grateful to two anonymous reviewers for their valuable comments on the earlier version of this paper.

Martyniv, L., Sokolova, A., Kurinna, S., Kopeliuk, O., Sediuk, I., \& Khomova, O. (2021). The modern problems and prospects of music formation and art education development during COVID-19. International Journal of Health Sciences, 5(3). https://doi.org/10.53730/ijhs.v5n3.2936 


\section{References}

Betts, D. J. (2006). Art therapy assessments and rating instruments: Do they measure up?. The Arts in psychotherapy, 33(5), 422-434. https://doi.org/10.1016/j.aip.2006.08.001

Black, J. (2009). Necessity is the mother of invention: Changing power dynamics between teachers and students in wired art classrooms. Canadian Review of Art Education: Research and Issues, 36, 99-117.

Black, J., \& Browning, K. (2011). Creativity in digital art education teaching practices. Art Education, 64(5), 1934.

Bryant, C. (2010). A 21st-century art room: The remix of creativity and technology. Art Education, 63(2), 4348.

Chauhan, A., \& Singh, R. P. (2020). Decline in PM2. 5 concentrations over major cities around the world $\begin{array}{llll}\text { associated with } & \text { COVID-19. Environmental } & \text { Research, 187, }\end{array}$ https://doi.org/10.1016/j.envres.2020.109634

Corakli, E., \& Batibay, D. (2012). The efficacy of a music education programme focused on creative thinking. Procedia-Social and Behavioral Sciences, 46, 3571-3576. https://doi.org/10.1016/j.sbspro.2012.06.107

Cotantino, T., Kellam, N., Cramond, B., \& Crowder, I. (2010). An interdisciplinary design studio: How can art and engineering collaborate to increase students' creativity?. Art Education, 63(2), 49-53.

Delacruz, E. M. (2009). Art education aims in the age of new media: Moving toward global civil society. Art Education, 62(5), 13-18.

Delacruz, E. M. (2009). From Bricks and Mortar to the Public Sphere in Cyberspace: Creating a Culture of Caring on the Digital Global Commons. International Journal of Education \& the Arts, 10(5), n5.

Derby, J. (2011). Disability studies and art education. Studies in Art Education, 52(2), 94-111.

Dewhurst, M. (2010). An inevitable question: Exploring the defining features of social justice art education. Art Education, 63(5), 6-13.

Dik, D. A., Morrison, R., Sabol, F. R., \& Tuttle, L. (2021). Looking beyond COVID-19: arts education policy implications and opportunities. Arts Education Policy Review, 1-9.

Dissanayake, E. (1995). What is art for? Seattle: University of Washington Press.

Flach, F. (1988). Resilience: Discovering a new strength at times of stress. Ballantine Books.

Glăveanu, V. P. (2018). Educating which creativity?. Thinking Skills and Creativity, 27, 25-32. https://doi.org/10.1016/j.tsc.2017.11.006

Gregory, D. C. (2009). Boxes with fires: Wisely integrating learning technologies into the art classroom. Art Education, 62(3), 47-54.

Guyotte, K. W., Sochacka, N. W., Costantino, T. E., Kellam, N. N., \& Walther, J. (2015). Collaborative creativity in STEAM: Narratives of art education students' experiences in transdisciplinary spaces. International journal of education \& the arts, 16(15).

Guyotte, K. W., Sochacka, N. W., Costantino, T. E., Walther, J., \& Kellam, N. N. (2014). STEAM as social practice: Cultivating creativity in transdisciplinary spaces. Art Education, 67(6), 12-19.

Han, H. C. S. (2019). Virtual World Construction and the Relationship to Creativity in Art Education. Canadian Review of Art Education: Research \& Issues, 46(1).

Heise, D. (2014). Steeling and resilience in art education. Art Education, 67(3), 26-30.

Henderson, N., Benard, B., \& Sharp-Light, N. (Eds.). (2007). Resiliency in action: Practical ideas for overcoming risks and building strengths in youth, families \& communities. Resiliency in Action.

Jokela, T., \& Huhmarniemi, M. (2018). Art-based action research in the development work of arts and art education. The lure of Lapland: A handbook of Arctic art and design.

Kirsten, R. (2021). Review of The Paradox of Creativity in Art Education: Bourdieu and Socio-Cultural Practice. Studies in Art Education, 62(1), 100-104.

Kistan, K., Malka, S., \& Musni, M. (2020). The relationship between knowledge, attitude, and readiness of academic community in Covid-19 spread prevention: Batari Toja Nursing Academy, Watampone. International Journal of Health \& Medical Sciences, 3(1), 72-78.

Kusumajaya, A. A. N. (2021). Individual and social environmental factor as risk factor of BMI-for-age in school children. International Journal of Health Sciences, 5(2), 89-98. https://doi.org/10.29332/ijhs.v5n2.1242 
Leal-Neto, O. B., Santos, F. A. S., Lee, J. Y., Albuquerque, J. O., \& Souza, W. V. (2020). Prioritizing COVID-19 tests based on participatory surveillance and spatial scanning. International journal of medical informatics, 143, 104263. https://doi.org/10.1016/j.ijmedinf.2020.104263

Li M., Wong, K. (2021) Mission Impossible: The Transformation of Performing Arts Education During COVID 19, EDULEARN21 Proceedings, p. 656.

Liu, Y., \& Chen, M. (2018). From the aspect of STEM to discuss the effect of ecological art education on knowledge integration and problem-solving capability. Ekoloji, 27(106), 1705-1711.

Rothenberg, A. (1990). Creativity in adolescence. Psychiatric Clinics of North America, 13(3), 415-434. https://doi.org/10.1016/S0193-953X(18)30351-4

Ryan D. Shaw \& Whitney Mayo (2021) Music education and distance learning during COVID-19: a survey, Arts Education Policy Review, DOI: 10.1080/10632913.2021.1931597

Sabol, R.F. (2010). Summary of findings from NCLB: A study of its impact upon art education programs. (Research Report Summary).

Sala, G., \& Gobet, F. (2017). When the music's over. Does music skill transfer to children's and young adolescents' cognitive and academic skills? A meta-analysis. Educational Research Review, 20, 55-67. https://doi.org/10.1016/j.edurev.2016.11.005

Shaw, R. D., \& Mayo, W. (2021). Music education and distance learning during COVID-19: a survey. Arts Education Policy Review, 1-10.

Silakarma, D., Adiputra, N., Sudewi, A. A. R., \& Widiana, I. G. R. (2021). Brain gym application and brain vitalization exercises in Balinese dance movement improves cognitive functions, quality of live and decreasing BDNF level in elderly. International Journal of Health Sciences, 5(2), 135-150. https://doi.org/10.29332/ijhs.v5n2.1356

Silvia, P. J. (2008). Another look at creativity and intelligence: Exploring higher-order models and probable

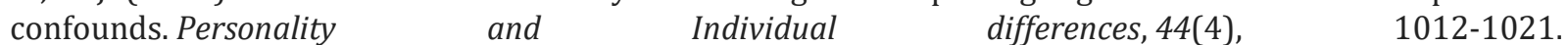
https://doi.org/10.1016/j.paid.2007.10.027

Stes, A., Min-Leliveld, M., Gijbels, D., \& Van Petegem, P. (2010). The impact of instructional development in higher education: The state-of-the-art of the research. Educational research review, 5(1), 25-49. https://doi.org/10.1016/j.edurev.2009.07.001

Topoğlu, O. (2014). Critical thinking and music education. Procedia-Social and Behavioral Sciences, 116, 22522256. https://doi.org/10.1016/j.sbspro.2014.01.554

Unrath, K. A., \& Mudd, M. A. (2011). Signs of change: Art education in the age of the iKid. Art Education, 64(4), 6-11.

Vuk, S., \& Bosnar, M. (2021). Process in contemporary visual art as a paradigm shift in the visual art education: perspective of creativity. Creativity Studies, 14(1), 99-111.

Widana, I.K., Sumetri, N.W., Sutapa, I.K., Suryasa, W. (2021). Anthropometric measures for better cardiovascular and musculoskeletal health. Computer Applications in Engineering Education, 29(3), 550561. https://doi.org/10.1002/cae.22202

Widjaja, G. (2021). Impact of human resource management on health workers during pandemics COVID-19: systematic review. International Journal of Health \& Medical Sciences, 4(1), 61-68.

Wolin, S. J., \& Wolin, S. (2010). The resilient self: How survivors of troubled families rise above adversity. Villard.

World Health Organization. (2019). What is the evidence on the role of the arts in improving health and wellbeing? A scoping review. World Health Organization. Regional Office for Europe.

$\mathrm{Xu}$ J. (2021). The Importance of Art Education During COVID-19 and Beyond.

Zimmerman, E. (2010). Reconsidering the role of creativity in art education. Art Education, 63(2), 4.

Martyniv, L., Sokolova, A., Kurinna, S., Kopeliuk, O., Sediuk, I., \& Khomova, O. (2021). The modern problems and prospects of music formation and art education development during COVID-19. International Journal of Health Sciences, 5(3). https://doi.org/10.53730/ijhs.v5n3.2936 


\section{Biography of Authors}

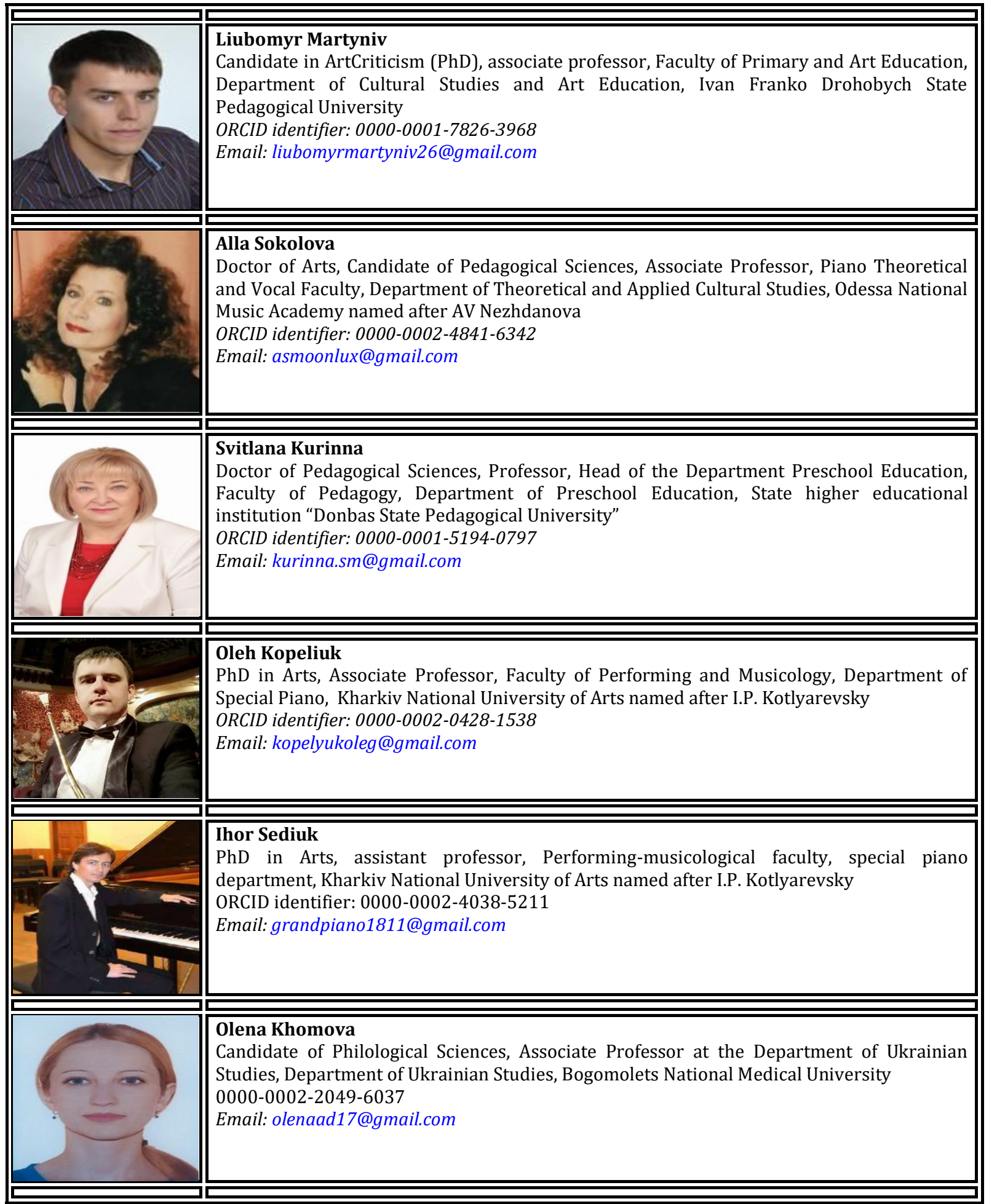

